\title{
An unusual habitat for hermit crab-associated alpheid shrimp Aretopsis amabilis De Man, 1910 (Crustacea: Decapoda: Alpheidae): a possible evidence of socially monogamous species?
}

\section{Необычное местообитание креветки-альфеиды Aretopsis amabilis De Man, 1910 (Crustacea: Decapoda: Alpheidae): свидетельство соџиальной моногамии?}

\author{
Ivan N. Marin \\ И.Н. Марин
}

A.N. Severtzov Institute of Ecology and Evolution of RAS, Leninsky Prosp. 33, Moscow, 117071 Russia.
E-mails: coralliodecapoda@mail.ru; vanomarin@yahoo.com
Институт проблем экологии и эволюции им. А.Н. Северцова РАН, Ленинский просп., 33, Москва 117071 Россия.

KEY WORDS: Caridea, Alpheidae, Aretopsis, hermit crab associated, unusual habitat, Vietnam.

КЛЮЧЕВЫЕ СЛОВА: Caridea, Alpheidae, Aretopsis ассоциированный с раками-отшельниками, необычное местообитание, Вьетнам.

ABSTRACT. A heterosexual pair of hermit crabassociated alpheid shrimp Aretopsis amabilis De Man, 1910 was found inside the empty shell of burrowing spatangid sea urchin of the genus Platybrissus. The finding and ecology as well as possibility of social monogamy in this shrimp species are discussed.

РЕЗЮМЕ. Разнополая пара креветок-альфеид Aretopsis amabilis De Man, 1910 - вида, обычно ассоциированного с раками-отшельниками, найдена живущей внутри пустого панциря зарывающегося морского ежа-спатангиды рода Platybrissus. Особенности находки, экологии и возможной социальной моногамии у этого вида креветок обсуждаюся в данной статье.

\section{Introduction}

Alpheid shrimp Aretopsis amabilis De Man, 1910 (Crustacea: Decapoda: Alpheidae) is well known throughout tropical shallow waters of Indo-West Pacific as an obligate symbiotic species living inside the gastropod shell occupied by large diogenid hermit crabs of the genera Dardanus Paulson, 1875 and Aniculus Dana, 1952 (Crustacea: Decapoda: Diogenidae) [De Man, 1910; Ramadan, 1936; Miyake \& Miya, 1966; Bruce, 1969; Banner \& Banner, 1979; Nomura, 1986; Chace, 1988; Williams \& McDermott, 2004; Marin, 2010]. The species is usually found in a male-female pair per a host [Bruce, 1969; Vannini et al., 1993; Marin, 2010; pers. observ.] sharing and possibly being in competition for the lumen of the shell with other specialized symbiotic crustaceans, such as copepods of the genera Paraidya Huys, 2009 (Crustacea: Copepoda: Harpacticoida: Tisbidae), Porcellidium Claus, 1860
(Crustacea: Copepoda: Harpacticoida: Porcellididae) and Sunaristes Hesse, 1867 (Crustacea: Copepoda: Harpacticoida: Canuellidae), mysid Heteromysis (Gnathomysis) harpax (Hilgendorf, 1878) (Crustacea: Mysidacea: Mysidae), amphipods of the genus Gitanopsis Sars, 1892 (Crustacea: Amphipoda: Amphilochidae) and other species [e.g. Vannini et al., 1993; Bacescu \& Bruce, 1980; review in Williams \& McDermott, 2004]. Most of known specialized hermit crab-associated species have never been observed outside of their hosts.

During the sampling in Nhatrang Bay in April 2013, as a part of long-term studying diversity of marine fauna [see Marin, 2005, 2007, 2009, 2012; Marin et al., 2005; Anker et al., 2006; Anker \& Marin, 2006; Marin \& Chan, 2006; Marin \& Savinkin, 2007; Marin \& Spiridonov, 2007], a pair of mature specimens of Aretopsis amabilis was found inside the empty shell of burrowing spatangid sea urchin. This is the first record of this highly specialized symbiotic shrimp species found outside its natural host keeping a malefemale pair and this finding can probably satisfy that this species is socially monogamous. Peculiarities of ecology of Aretopsis amabilis and remarks on known cases of social monogamy in caridean shrimps are discussed below.

\section{Material and methods}

The echinoid shell of the genus Platybrissus Grube, 1866 (Echinodermata: Echinoidea: Irregularia: Spatangidea: Eurypatagidae) was collected from muddy sand at the depth of $15 \mathrm{~m}$ near Nok Island (Hon Nok), situated close to the eastern cape of Tre Island, Nhatrang Bay, South Vietnam at April 2013. The shell was 
found freely laying on bottom partly covered by silt; no large hermit crabs were recorded around the shell. After getting the shell into laboratory and cleaning for further identification two shrimp specimens were washed out from the inner space of the shell and fixed in $40 \%$ solution of ethanol. After careful examination in the laboratory they were identified as highly specialized hermit crab - associated alpheid shrimps Aretopsis amabilis De Man, 1910 (Crustacea: Decapoda: Alpheidae). Carapace length (cl, in $\mathrm{mm}$ ) and total body length (tl., in $\mathrm{mm}$ ) are used as a standard measurement of size. The material is deposited in Laboratory of Ecology and Morphology of Marine Invertebrates of A.N. Severtzov Institute of Ecology and Evolution (LEMMI).

\section{Taxonomy \\ Order Decapoda Latreille, 1802 \\ Suborder Natantia Boas, 1880 \\ Family Alpheidae Rafinesque, 1815 \\ Genus Aretopsis De Man, 1910}

\section{Aretopsis amabilis De Man, 1910}

Aretopsis amabilis De Man, 1910: 311 (type locality: Pulau Kaniungan-Ketjil, Borneo); 1911:171, pl. 4: figure 14.

Aretopsis aegyptiaca Ramadan, 1936: 16, pls. 1, 2: figures 917 (type locality: Hurghada, Egypt, Red Sea).

MATERIAL EXAMINED: 1 ovigerous + , cl $8.0 \mathrm{~mm}$, tbl 21.0 $\mathrm{mm} ; 1 \mathrm{O}^{7}$, cl $5.8 \mathrm{~mm}$, tbl. $17.0 \mathrm{~mm}$, LEMMI, Pacific Ocean, South China Sea, Vietnam, Nhatrang Bay, eastern cape of Tre Island, Nok Island (Hon Nok), $15 \mathrm{~m}$ depth, muddy sand, inside echinoid shell of the genus Platybrissus. Collected by O. Bratova, 12 April 2013.

ECOLOGICAL REMARKS: The examined shrimps represent a heterosexual pair consisting of large ovigerous female and large mature male. Aretopsis amabilis has been exclusively recorded inside gastropod shells occupied by large diogenid hermit crabs of the genus Dardanus, such as Dardanus megistos (Herbst, 1804), D. sanguinolentus (Quoy et Gaimard, 1824) and D. lagopodes (Forskål, 1775), and a species of the genus Aniculus [e.g. Bruce, 1969; Banner \& Banner, 1968, 1979]. The species was reported from same locality before as a symbiont of shallow-water large hermit crabs Dardanus cf. lagopodes (Forskål, 1775) (Crustacea: Decapoda: Diogenidae) [Marin, 2010].

DISTRIBUTION: Known from the Red Sea, Madagascar, Seychelles and Maldives, Indonesia, Vietnam, Philippines, Japan, Australia and Marshall Islands [Ramadan, 1936; Miyake \& Miya, 1966; Banner \& Banner, 1968, 1979; Bruce, 1969, 1984; Nomura, 1986; Chace, 1988].

\section{Discussion}

The present record is interesting as highly specialized symbiotic species has been found outside its natural host keeping a male-female pair. Such a case suggests several scenarios: 1) shrimps occupied the dead sea urchin shell (non-specific host) settling primary from plankton and forming breeding heterosexual pair; 2) shrimps were associated with the recorded "natural host" (hermit crab) until the latter had dead and than migrated (keeping a pair) to the nearest suitable refuge (the empty shell of sea urchin). The second hypothesis seems to be more realistic as this shrimp species has been usually reported as highly adapted symbiont having specific morphology and feeding of faeces of its host [e.g. Vannini et al., 1993]. They were never collected outside of the natural hosts. Thus, attraction of larvae, settlement and further survival on non-specific substratum is doubtfullness event. Having summarized information presented above it is possible to suggest that the shrimps abandoned the host, probably, caused by the death of host hermit crab and further absence of food (crab faeces), and later found nearest refuge where they have survived feeding on detritus till the collection. Hermit crabs have never been recorded using shells of dead spatangid sea urchins because the latter are very fragile. The case that shrimps have kept the pair outside of the host showing that the species is socially monogamous and the mechanism of keeping paired distribution is not exclusively based on an expulsion of the same sex individuals from the host known for other symbiotic shrimp species [e.g. Marin, 2006; unpublished; Toth \& Bauer, 2008; Wong \& Michiels, 2011]. It is also showing that symbiotic shrimps can recognize the specific partner and try to keep a pair staying near outside of the natural host even during the migrations.

Social monogamy is relatively rare in the animal kingdom and varies greatly across different groups; over $90 \%$ of avian species and only 3\% of mammalian species are socially monogamous, although up to $15 \%$ of species are monogamous in primate species [e.g. Reichard, 2002]. Social monogamy has also been observed in reptiles, fish, insects and caridean shrimps. Known socially monogamous alpheids shrimp species belong to genera Alpheus Fabricius, 1798, Betaeus Dana, 1852 and Betaeopsis Yaldwin, 1971 [Rahman et al., 2003; Dabbagh et al., 2012; Anker \& Baeza, 2012]. Several alpheid species belonging to the genus Synalpheus Spence Bate, 1888 are the only non-insect arthropods known to be eusocial [Duffy, 1996; Duffy \& Macdonald, 1999; Didderen et al., 2006].

ACKNOWLEDGEMENTS. The study was supported by Russian-Vietnam Tropical Centre, Grant of the President of the Russian Federation MK-4481.2014.4 and RFFI project 12-04-00540-a. Author is very thankful to PhD student Olga Bratova (IPEE RAS) for sampling this material and identification of the sea urchin shell, and Dr. Vasily A. Spiridonov (IO RAS) for critical reviewing of the manuscript.

\section{References}

Anker A., Poddoubtchenko D., Marin I. 2006. On the presence of the alpheid shrimp genus Bermudacaris Anker and Iliffe, 2000 (Crustacea: Decapoda: Caridea) in the Pacific Ocean, with 


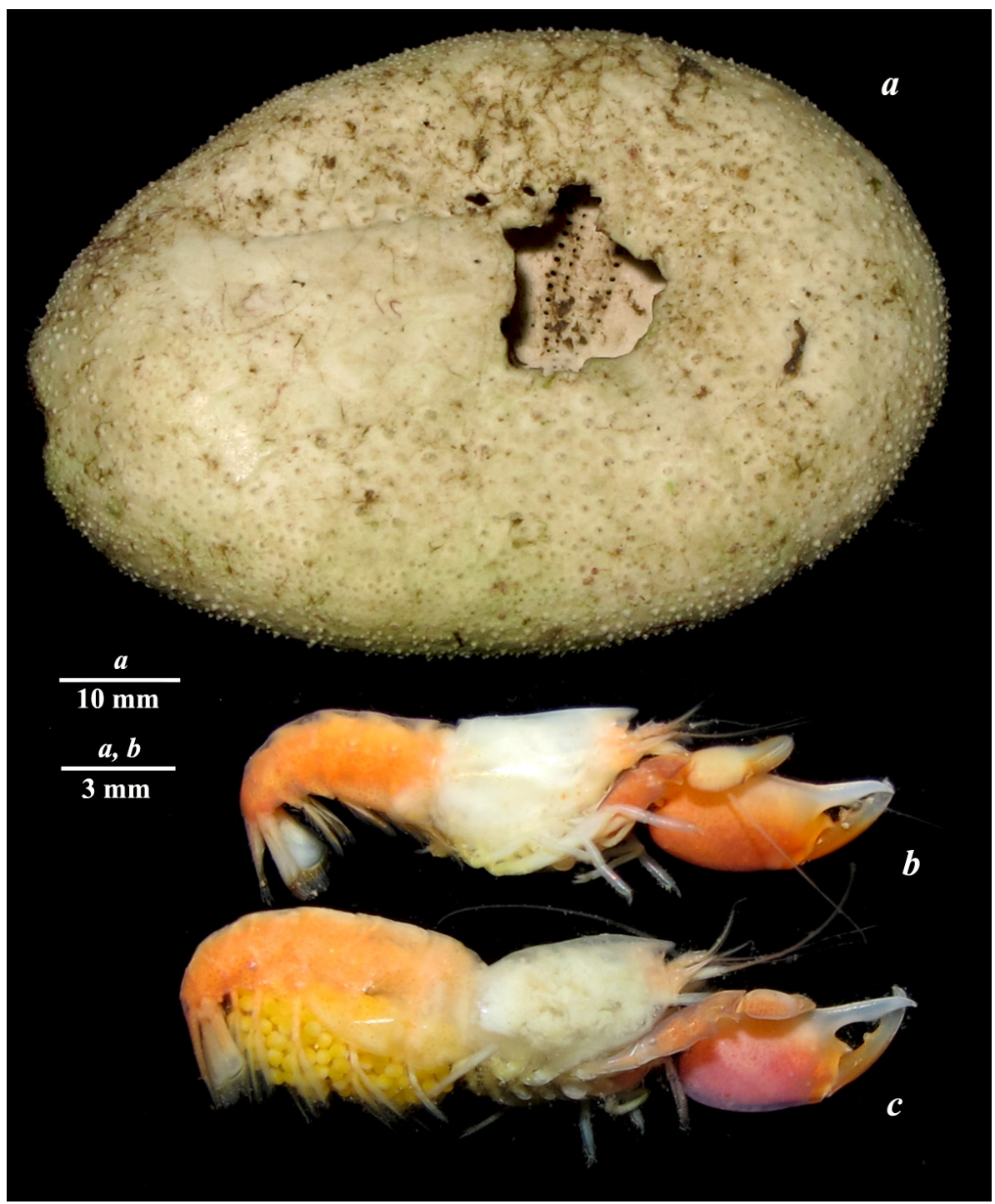

Fig. 1. a - empty shell of sea urchins (the length of shell is about $120 \mathrm{~mm}$ ); shrimps Aretopsis amabilis (b) mature male (cl. $5.8 \mathrm{~mm}$, tbl. $17.0 \mathrm{~mm}$ ) and (c) ovigerous female (cl. $8.0 \mathrm{~mm}$, tbl. $21.0 \mathrm{~mm}$ ) (coloration of fixed animals).

Рис. 1. а - пустой панцирь морского ежа (длина 120 мм); креветки Aretopsis amabilis (b) половозрелый самец (cl. 5,8 мм, tbl. 17,0 мм) и (c) половозрелая самка (cl. 8,0 мм, tbl. 21,0 мм) (окраска фиксированных животных).

description of a new species from Vietnam // Journal of Natural History. Vol.40. No.27-28. P.1675-1686.

Anker A., Marin I.N. 2006. New records and species of Alpheidae (Crustacea: Decapoda) from Vietnam. Part I. Genus Salmoneus Holthuis, 1955 // Raffles Bulletin of Zoology. Vol.54. No.2. P.295-319.

Anker A., Baeza J.A. 2012. Morphological and molecular phylogeny of hooded shrimps, genera Betaeus and Betaeopsis (Decapoda, Caridea, Alpheidae): testing the Center of Origin biogeographic model and evolution of life habits // Molecular Phylogenetics and Evolution. Vol.64. No.3. P.401-415.

Bacescu M., Bruce A.J. 1980. New contributions to the knowledge of the representatives of the genus Heteromysis s.1. from the Australian coral reefs // Travaux du Museum d'Histoire Naturelle 'Grigore Antipa'. Vol.21. P.63-72.

Baeza J.A., Farías, N.E., Luppi T.A., Spivak E.D. 2010. Habitat size, social grouping and symbiosis: testing the "resource economic monopolization" hypothesis with the shrimp Betaeus lilianae and description of its partnership with the crab Platyxanthus crenulatus // Journal of Experimental Marine Biology and Ecology. Vol.389. No.1-2. P.85-92.
Banner A.H., Banner D.M. 1968. Contributions to the knowledge of the alpheid shrimp of the Pacific Ocean, part XII: collections from the Marshall and Caroline Islands // Micronesica.Vol.4. P.261-294.

Banner A.H., Banner D.M. 1979 [1980]. Some small collections of alpheid shrimp from the Indian Ocean, including two new species of the genus Synalpheus // Pacific Science. Vol.33. P.25-35.

Bruce A.J. 1969. Aretopsis amabilis De Man, an alpheid shrimp commensal of pagurid crabs in the Seychelle Islands // Journal of the Marine Biological Association of India. Vol.11. P.175-181.

Chace F.A. 1988. The caridean shrimps (Crustacea: Decapoda) of the Albatross Philippine Expedition, 1907-1910, Part 5: family Alpheidae // Smithsonian Contributions to Zoology. Vol.466. P.1-112.

Dabbagh A.-R., Kamrani E., Taherizadeh M.R. 2012. Studies on Social Monogamy in the Snapping Shrimp, Alpheus lobidens De Haan, 1849 // Asian Journal of Animal and Veterinary Advances. Vol.7. No.4. P.361-365.

De Man J.G. 1910. Diagnoses of new species of macrurous decapod Crustacea from the "Siboga-Expedition" // Tijdschrift der 
Nederlandsche Dierkundige Vereeniging. Vol.11. No.2. P.287-319.

Didderen K., Fransen C.H.J.M., de Voogd N.J. 2006. Observations on Sponge-Dwelling Colonies of Synalpheus (Decapoda, Alpheidae) of Sulawesi, Indonesia // Crustaceana. Vol.79. P. $961-975$.

Duffy J.E. 1996. Eusociality in a coral-reef shrimp // Nature. Vol.381. P.512-514.

Duffy J.E., Macdonald K.S. 1999. Colony Structure of the Social Snapping Shrimp Synalpheus filidigitus in Belize // Journal of Crustacean Biology. Vol.19. P.283-292.

Fishelson L. 1971. Ecology and distribution of the benthic fauna in the shallow waters of the Red Sea // Marine Biology. Vol.10/2. P.113-133.

Marin I.N. 2005. Pontoniine shrimps (Crustacea, Decapoda, Pontoniinae) from Viet Nam. Onycocaris temiri sp. n., a new sponge-associated shrimp from Nha Trang Bay // Arthropoda Selecta. Vol.13. No.3. P.113-122.

Marin I.N. 2006. [Symbiotic community, associated with corals of genus Galaxea Oken (Cnidaria, Scleractinia): structure, biological interactions and ways of the formation]. Autoreferate of the Thesis of Candidate (Ph.D.) of Biological Sci. Degree. Moscow: A.N. Severtzov Institute of Ecology and Morphology of RAS. 107 p. [in Russian].

Marin I.N. 2007. A new genus and species of pontoniine shrimps (Caridea: Palaemonidae: Pontoniinae) associated with plumulariid hydroids (Hydroidea, Plumularidae) in Vietnam // Zoosystema. Vol.29. No.4. P.775-786.

Marin I. 2009. Crinoid-associated shrimps of the genus Laomenes A.H. Clark, 1919 (Caridea: Palaemonidae: Pontoniinae): new species and probable diversity // Zootaxa. Vol.1971. P.1-49.

Marin I. 2010. On the presence of the symbiotic alpheid shrimp Aretopsis amabilis in the coastal waters of Nhatrang Bay, Vietnam // Marine Biodiversity Records. Vol.3. No.1. P.1-4.

Marin I.N. 2012. New records and associations of pontoniine shrimps (Crustacea: Decapoda: Caridea: Palaemonidae: Pontoniinae) from the Nhatrang Bay, Vietnam; with taxonomic remarks on some species from the Indo-West Pacific region // Britayev T.A., Pavlov D.S. (eds.). Benthic fauna of the Bay of Nhatrang, Southern Vietnam. Moscow: KMK Scientific Press. Vol.2. P.345-405.

Marin I., Chan T.-Y. 2006. Two new genera and a new species of crinoid-associated pontoniine shrimps (Decapoda: Caridea: Palaemonidae) // Journal of Crustacean Biology. Vol.26. No.4 P.524-539.

Marin I., Britayev T., Anker A. 2005. Pontoniine shrimps associated with cnidarians: new records and list of species from coastal waters of Viet Nam // Arthropoda Selecta. Vol.13. Vol.4. P.199-218.

Marin I.N., Savinkin O.V. 2007. Further records and preliminary list of pontoniine (Caridea: Palaemonidae: Pontoniinae) and hymenocerid (Caridea: Hymenoceridae) shrimps from Nhatrang Bay // Britayev T.A., Pavlov D.S. (eds.). Benthic fauna of the Bay of Nhatrang, Southern Vietnam. Moscow: KMK Scientific Press. Vol.2. P.175-208.

Marin I.N., Spiridonov V.A. 2007. Corall-associated crabs (Decapoda: Domecidae, Trapeziidae, Tetraliidae, Xanthidae: $\mathrm{Cy}$ moinae) from Nhatrang Bay // Britayev T.A., Pavlov D.S. (eds.). Benthic fauna of the Bay of Nhatrang, Southern Vietnam. Moscow: KMK Scientific Press. Vol.2. P.209-234.

Miyake S., Miya Y. 1966. A rare alpheid shrimp Aretopsis amabilis De Man from the Ryukyu Islands (Decapoda, Crustacea) // Journal of the Faculty of Agriculture, Kyushu University. Vol.14. P.267-273.

Nomura K. 1986. Description of a shrimp, Aretopsis amabilis De Man (Decapoda Alpheidae) from Kushimoto, the Kii Peninsula, with some remarks on the genus Aretopsis from Japan // Nanki Sebutsu. Vol.28. P.7-10.

Rahman N., Dunham D.W., Govind C.K. 2003. Social Monogamy in the Big-Clawed Snapping Shrimp, Alpheus heterochelis // Ethology. Vol.109. No.6. P.457-473.

Ramadan M.M. 1936. Report on a collection of Stomatopoda and Decapoda from Ghardaga, Red Sea // Bulletin of the Faculty of Science, The Egyptian University. Vol.6. P.1-43.

Reichard U.H. 2002. "Monogamy - a variable relationship" // Max Planck Research. Vol.3. P.62-67.

Toth E., Bauer R.T. 2008. Synalpheus paraneptunus (Crustacea: Decapoda: Caridea) populations with intersex gonopores: a sexual enigma among sponge-dwelling snapping shrimps // Invertebrate Reproduction and Development. Vol.51. No.1. P.49-59.

Williams J.D., McDermott J.J. 2004. Hermit crab biocoenoses: a worldwide review of the diversity and natural history of hermit crab associates // Journal of Experimental Marine Biology and Ecology. Vol.305. P.1-128.

Wong J.W.Y., Michiels N.K. 2011. Control of social monogamy through aggression in a hermaphroditic shrimp // Frontiers in Zoology. Vol.8. P.30.

Vannini M., Innocenti G., Ruwa R.K. 1993. Family group structure in mysids, commensals of hermit crabs (Crustacea) // Tropical Zoology. Vol.6. No.1. P.189-205.

Responsible editor V.A. Spiridonov 